\title{
色素結合薄膜型（岡山大学方式）の
} 人工網膜 $\left(O U R e P^{T M}\right)$ の医師主導治験

松尾俊颜草，内田哲也 ${ }^{\mathrm{b}}$

$\mathrm{a}$ 岡山大学大学院医歯薬学総合研究科 眼科学, b岡山大学大学院自然科学研究科 高分子材料学

キーワード : 人工網膜, OUReP, 医師主導治験, 色素結合薄膜, 網膜色素変性

\section{Investigator (doctor)-initiated clinical trial of photoelectric dye-coupled thin film (Okayama University-type) retinal prosthesis}

Toshihiko Matsuo $^{a *}$, Tetsuya Uchida ${ }^{b}$

aDepartment of Ophthalmology, Okayama University Graduate School of Medicine, Dentistry and Pharmaceutical Sciences,

bepartment of Polymer Materials Science, Okayama University Graduate School of Natural Science and Technology

\section{研究の概要}

視細胞が死滅する疾患である網膜色素変性は, 視細 胞の機能を代替する人工網膜で視覚を再生できる（図 $1)^{1)}$. 岡山大学方式の人工網膜 $\left(\mathrm{OUReP}^{\mathrm{TM}}\right.$ オーレッ プ, 岡山大学登録商標, class III医療機器）は, 光電変 換色素をポリエチレンフィルム表面に化学結合させた 世界初の新方式「色素結合薄膜型」の人工網膜である

(図 $2 \sim 5)^{2-7}$. 2002年, 岡山大学発のシーズとして 医工連携の開発研究を始め, 2016年, first-in-human 医 師主導治験を開始する予定である（図 3 ). 基本特許は 岡山大学が保有 ${ }^{8-10)}$, 製造と品質管理に関する補強特 許も2014年に岡山大学から出願した.

世界中で開発中の人工網膜はカメラ撮像を画像処理 して伝送し眼球内網膜近傍に植込んだ電極集合体（ア レイ）から電流を出力する方式で，2013年，アメリカ で初めて製造販売承認された (図 5$)^{1)}$ 。岡山大学方式 の人工網膜は，電流出力ではなく光を受けて電位差を 生じ，近傍の網膜神経細胞を刺激して視覚を生む新方 式である(図 2$)^{11-15)}$ 。生物学的安全性評価で毒性はな い(図 4 ).

2013年 1 月 PMDA 事前面談を皮切りに工学部製造 品による治験を相談し，2014年 6 月30日の対面助言， 2015年 6 月15日の対面助言で非臨床試験の充足性及び

平成 27 年 8 月受理

* ₹700-8558 岡山市北区鹿田町 2-5-1

電話：086-235-7297 FAX：086-222-5059

E-mail :matsuot@cc.okayama-u.ac.jp
品質の妥当性, 治験実施計画書について助言を受けた。 2014年12月，岡山県ものづくり中小企業である三乗 (みのり）工業(株)と岡山大学が共同研究契約を結び, 2015年 1 月，中小企業基盤整備機構の岡山大インキュ ベータに入居し，クリーンルーム製造ラインを構築し た（図 6 ).

2016年，完全失明の網膜色素変性患者 5 人が参加す る first-in-human feasibility study（探索的試験）の医 師主導治験では，内田哲也が治験機器提供者となり， 松尾俊彦が治験責任医師として硝子体手術で人工網膜 を植込む予定である。

\section{研究の背景}

網膜色素変性は視細胞が徐々に死滅してゆく遺伝性 疾患である。視野が次第に狭くなり，最終的には視力 が低下して失明する（図 1 )。その治療方法は現状では ない，視細胞の機能を人工物で代替する人工網膜が治 療候補として有望で，2013年にはアメリカで初めて人 工網膜が Food and Drug Administration (FDA) によ って製造販売承認された (図 5$)^{1)}$.

このアメリカの人工網膜はカメラで取り込んだ映像 を60画素に画像処理して，その信号を顔面皮内に植込 んだ受信機に伝送し，その受信機から60本の電線を出 して眼球内に挿入し，網膜表面に固定した60個の電極 集合体 (アレイ) から電流を出力する (図 5 ). 出力電 流によって網膜内に残っている神経節細胞が刺激され てその軸索である視神経を通って後頭葉に伝わり視覚 を生じることを期待している。アメリカの人工網膜に 


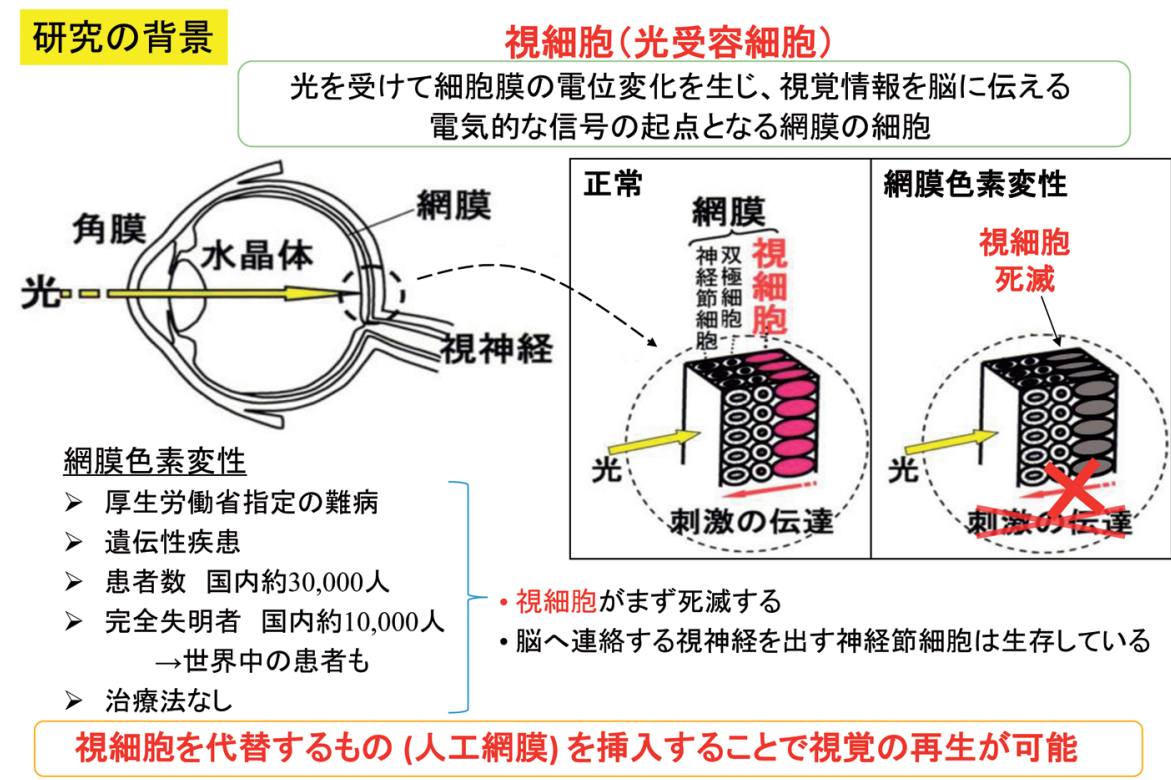

図 1 網膜色素変性における視細胞の死滅と人工網膜による視覚再生

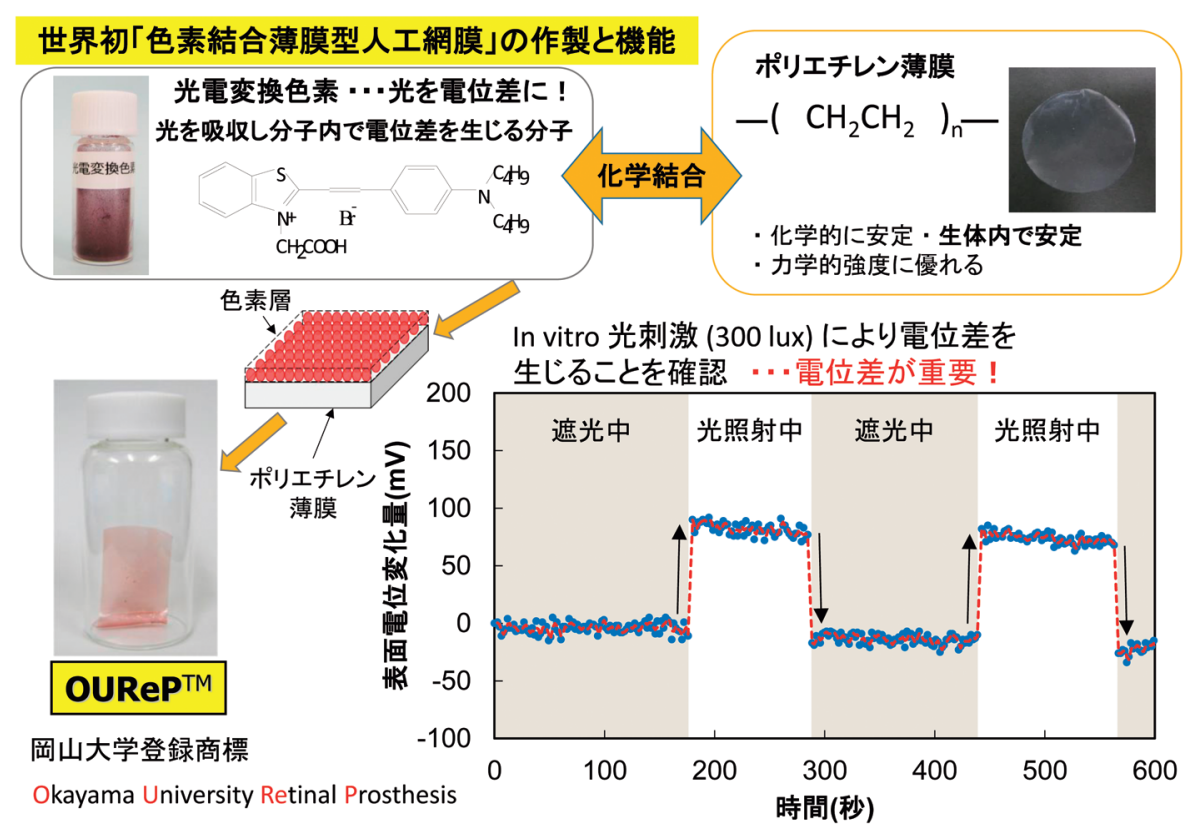

図 2 世界初「色素結合薄膜型人工網膜 $O U R e \mathrm{P}^{\mathrm{TM}} 」$ の作成と機能

よって完全失明した患者が光覚を回復することが可能 となっだ .

このカメラ撮像・電極アレイ方式の人工網膜は, ア メリカだけでなく日本も含めた世界中で開発されてい る.問題は, 構造が複雑で植込みの手術手技が難しい, 電極の小型化が難しく分解能が悪い（つまり見えな い),広い面積の網膜を刺激することができず視野が狭
い, 1,000万円を超える高額医療機器である, などの点 である。

\section{研究の画期性}

私たちは，アメリカの人工網膜とは全く異なる世界 初の新方式である「色素結合薄膜型」の人工網膜を 2002 年から医工連携で研究開発してきた (図 2$)^{2-15}$. 光を 


\section{標準的な硝子体手術で対応できる！}

\section{OURePTM}

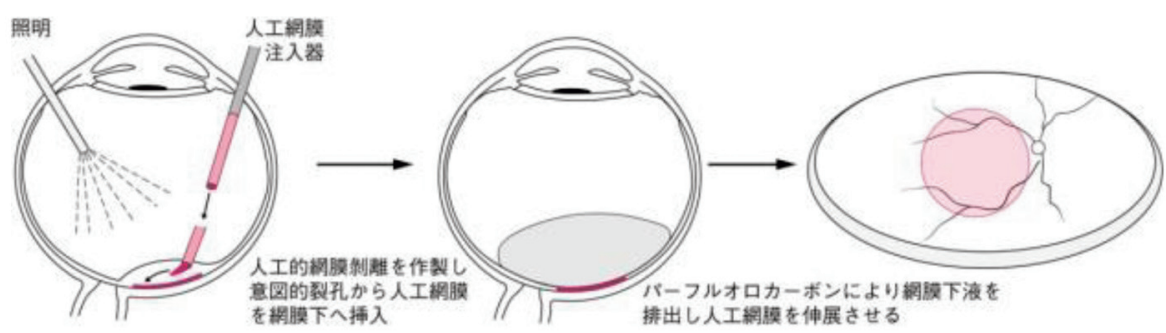

【特徴】

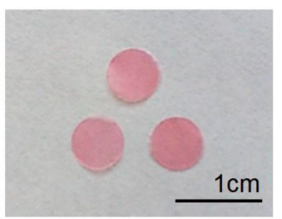

挿入する「人工網膜」の例

、薄くて柔らかい

•大面積のものを丸めて㨂入できる $\rightarrow$ 広い視野が得られる

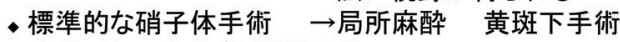

・患者ごとにサイズを調整可能

・生体適合性がよい

-フィルム表面の高密度分子 $\rightarrow$ 高解像度

、先行機器アメリカ人工網膜 (約1500万円) より低価格

図 3 硝子体手術による色素結合薄膜型人工網膜 OUReP $P^{\mathrm{TM}}$ の植込み

\section{生物学的安全性評価 実施の全試験で毒性なし}

\section{OUREPTM}

$>$ 人工網膜 GLP 試験

$>$ 光電変換色素分子単独 non-GLP 試験

GLP試験とは・・厚生労働省令に基づく医療機器の

安全性評価のための非臨床試験

In vivo動物モデル 行動評価から「見えている」!

動物の視覚は

行動実験で判定するしか方法がない

・動物の行動実験で視覚を証明した

世界で初めての人工網膜

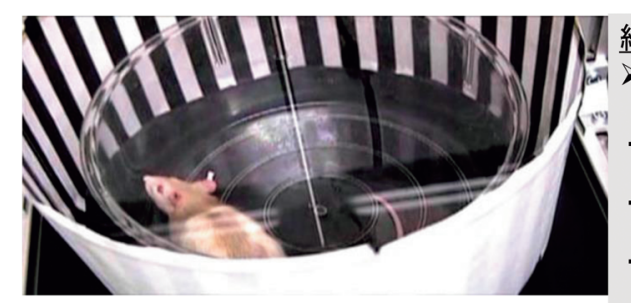

網膜色素変性 (RCS) ラットを用いた検証 行動実験による視覚回復

\section{$\rightarrow$ 視力 0.005 以上}

人工網膜挿入ラットのまわりで白黒縞模様の円筒を

時計方向、反時計方向に $2 \mathrm{rpm}$ で回転させる

・円筒の回転方向に一致した首振り運動の回数を 記録する

・対照ラット(ポリエチレンフィルム挿入)と比較する

\section{網膜電図 (ERG) の記録 $\rightarrow$ 反応あり}

視覚誘発電位 (VEP) の記録 $\rightarrow$ 反応あり

図 4 色素結合薄膜型人工網膜 $\mathrm{OUReP} \mathrm{P}^{\mathrm{TM}}$ の生物学的安全性と有効性

吸収して電位差を出力する光電変換色素分子をポリエ チレン薄膜（フィルム）に化学結合した岡山大学方式 の人工網膜 $\left(\mathrm{OUReP} \mathrm{P}^{\mathrm{TM}}\right)$ である。この新方式の人工網 膜は, 電流を出力するのではなく, 光を受けて電位差を 出力し, 近傍の神経細胞を刺激することができる(図 5 ).

「色素結合薄膜型」の人工網膜は薄くて柔らかいの で，大きなサイズ（直径 $5 \sim 10 \mathrm{~mm}$ 大）のものを丸めて
小さな切開創から眼球内の網膜下へ植込むことが可能 である（図 3 )。その手術は現在すでに確立している黄 斑下手術の手技で実施できる。大きなサイズ（面積） の人工網膜なので得られる視野は広く，人工網膜表面 の多数の色素分子が網膜の残存神経細胞を 1 つずつ刺 激するので，視覚の分解能も高い.人工網膜の原材料 も安価なので，手の届く適正な価格にて供給できる. 


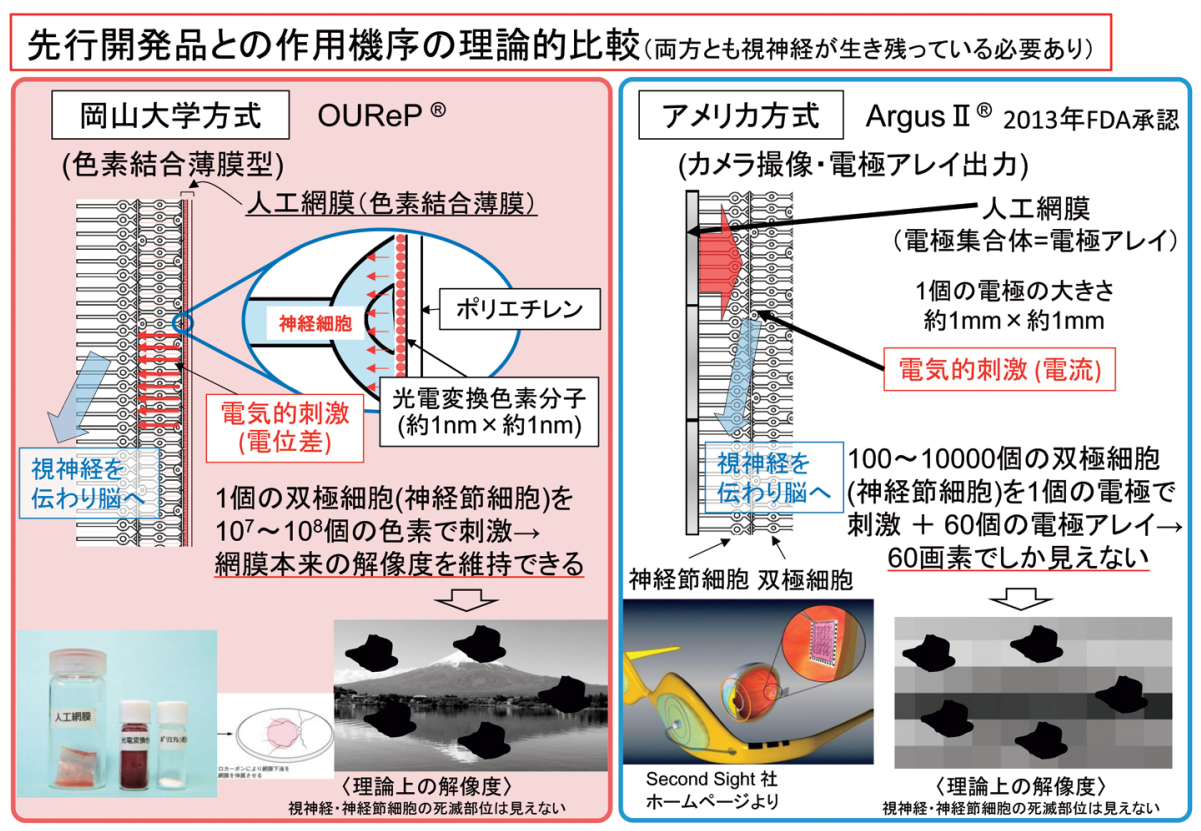

図 5 色素結合薄膜型人工網膜 $\mathrm{OUReP} \mathrm{P}^{\mathrm{TM}}$ とアメリカのカメラ撮像・電極アレイ型人工網膜の原理の違い
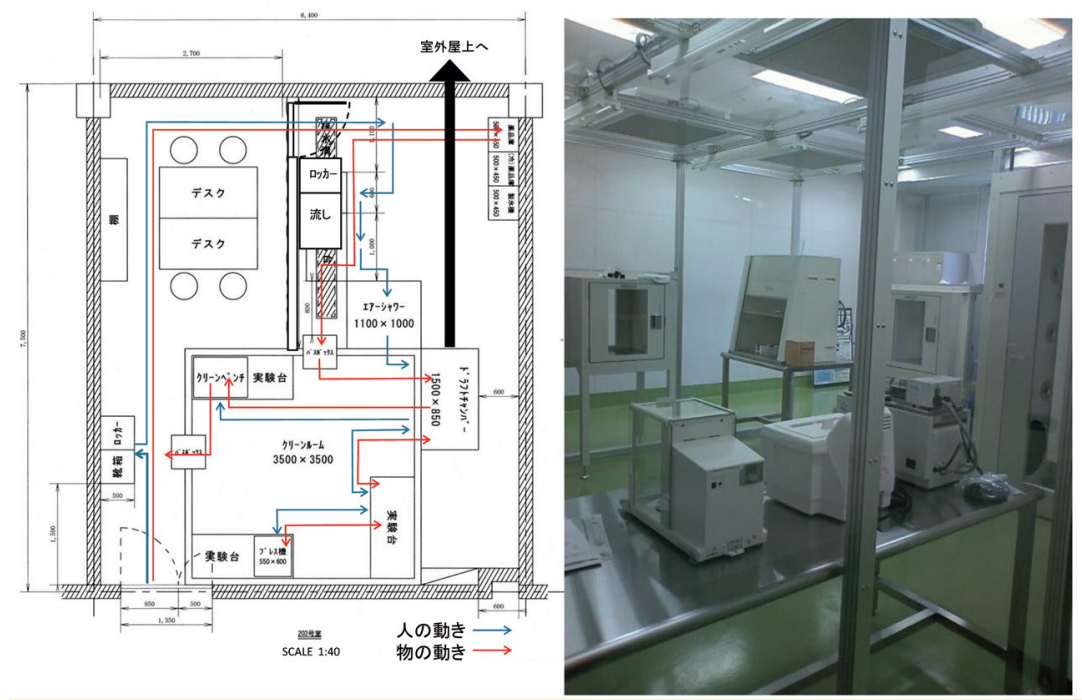

人工網膜 (OURePTM) の岡山大インキュベータ クリーンルーム製造施設

図 6 中小企業基盤整備機構の岡山大インキュベータに構築した色素結合薄膜型人工網膜 $\mathrm{OUReP}^{\mathrm{TM}}$ のクリーンルーム製造施設

\section{これまでに取得した非臨床 POC (proof of concept)}

1. 人工網膜 $\left(\mathrm{OUReP} \mathrm{P}^{\mathrm{TM}}\right)$ の有効性として下記項目を 実証した

1 ）神経細胞の反応

人工網膜に接した培養神経細胞は, 光照射下で細胞 内カルシウム上昇反応を起こす ${ }^{12,13)}$. この反応は, 電
位作動性カルシウム・チャンネル阻害薬で打ち消される.

2 ) 動物での視覚改善

網膜色素変性ラット（RCS ラット）を使って，若い 6 週齢ラット，および，高齢の 14 週齢ラットに人工網 膜 $\left(\mathrm{OUReP} \mathrm{P}^{\mathrm{TM}}\right)$ を植込み, 対照ラットにはポリエチレ ンフィルムを植込んだ。対照ラットに比べて人工網膜 を植込んだラットでは，術後 8 週間にわたって行動実 
験による視覚が改善された（図 4$)^{16,17)}$.

3 ) 動物での網膜電図, 視覚誘発電位の記録

6 週齢 RCS ラットに人工網膜 $\left(\mathrm{OUReP} \mathrm{P}^{\mathrm{TM}}\right)$ を植込 み, ポリエチレンフィルムを植込んだ対照ラット, 無 処置の対照ラットと比較した. 術後 4 週目に人工網膜 を植込んだラットでは網膜電図が高頻度に記録された ${ }^{17)}$ 。 また，視覚誘発電位も記録された（図 4 ）。

4 ) 動物での長期埋植による網膜神経細胞死の抑制

6 週齢 RCS ラットに人工網膜 (OUReP $\left.{ }^{\mathrm{TM}}\right)$ を植込 み, その 5 カ月後には網膜神経組織のアポトーシスは 抑制された ${ }^{17)}$.

\section{2 . 人工網膜 $\left(\mathrm{OUReP}^{\mathrm{TM}}\right)$ の安全性として下記項目を 実証した}

薬食機発0301第20号（平成24年 3 月 1 日)「医療機器 の製造販売承認申請等に必要な生物学的安全性評価の 基本的考え方」に基づくGLP (good laboratory practice) 試験として, 細胞毒性試験, 感作性試験（皮虚感作性 試験), 遺伝毒性試験 (復帰突然変異試験, 染色体異常 試験), 刺激性試験 (眼刺激性試験), 全身毒性試験 (急 性毒性試験)，埋植試験（28日間）を行った。すべての 試験で一切の毒性を認めなかった.2014年11月から「6 カ月埋植試験」を年度を跨ぐ計画で実施している.

人工網膜の部材である光電変換色素分子による非 GLP 試験として, 細胞毒性試験, 感作性試験（皮膚感 作性試験), 遺伝毒性試験 (復帰突然変異試験, 染色体 異常試験), 刺激性試験 (眼刺激性試験), 全身毒性試 験（急性毒性試験, 28日間反復投与の亜急性毒性試験） を行った。すべての試験で色素分子自体にも一切の毒 性はなかった。

\section{患者会との連携}

患者団体（日本網膜色素変性協会 Japan Retinitis Pigmentosa Society：JRPS)の都道府県支部において, 臨床担当（治験責任者／治験責任医師）の松尾俊彦と 製造担当（治験機器提供者）の内田哲也の二人による 講演会を行った。2013年 1 月14日の岡山市（岡山県支 部), 2013年12月 1 日の神戸市 (兵庫県支部), 2014年 5 月 25 日の松山市 (愛媛県支部), 2014年 7 月 20 日の金 沢市 (石川県支部), 2015年 5 月17日の徳島市 (徳島県 支部）での講演会である.

\section{実用化時の製品イメージと市場規模}

対象とするユーザーは網膜色素変性で失明した患
者，国内 1 万人である.ターゲット市場規模は以下の ように考える。人工網膜の販売価格は仮にペースメー カーと同等の 100 万円と想定する.網膜色素変性の患者 のうち失明した患者数は 1 万人， 1 万人のうち $80 \%$ が 手術にアクセス可能で, 両眼手術を受けると想定する. $10,000 \times 0.8 \times 2 \times 100$ 万円 $=160$ 億円 (将来は海外市場 4,800億円もターゲット）となる.

製品（標準治療化）イメージとしては，現在の市場 の状況は，日本製の既存製品はなく，海外製の既存製 品はアメリカ一社(Argus II Retinal Prosthesis System, Second Sight, Inc., USA，2013年 2 月 FDA 承認）の みである。

2020年の市場イメージとしては，日本全国，世界中 の施設で硝子体手術医が実施可能な手術となる。カメ ラ電極アレイ方式の人工網膜（約 1,500 万円）より安価 で, iPS 細胞治療より安価である。

\section{開発トラックの考え方及び実用化に向けたハードル}

開発トラックの考え方としては，工学部製造品で first-in-human feasibility study を医師主導治験として 行い，それと並行して企業に技術移転し，企業製造品 で pivotal study を行い, 医療機器製造販売承認を申請 する。

実用化に向けた主なハードルとしては，医療機器の 生物学的安全性評価の 6 力月埋植試験，品質保証のた めの加速試験, first-in-human feasibility study 医師主 導治験である。

\section{医療行政・規制当局との対応}

医薬品医療機器総合機構（PMDA）と行った薬事戦 略相談を時系列で示す。

2013年 1 月11日, PMDA 事前面談：松尾俊彦, 内田哲 也

2013年 9 月 2 日, 中国経済産業局（広島市）「医の芽ネ

ット」PMDA 相談会：内田哲也

2014年 2 月21日, PMDA 事前面談：松尾俊彦，内田哲 也

2014年 4 月21日, PMDA 事前面談：松尾俊彦，内田哲 也

2014年 6 月 30 日, PMDA 対面助言：松尾俊彦, 内田哲 也, 石坂春彦

相談内容の概略「非臨床試験の充足性及び品質の妥 当性」 
2014年10月24日, PMDA 事前面談：松尾俊彦, 内田哲 也，石坂春彦

2015年 3 月 20 日, PMDA 事前面談：松尾俊彦, 内田哲 也, 石坂春彦, 蔵本孝一

2015年 6 月 15 日, PMDA 対面助言：松尾俊彦, 内田哲 也, 櫻井淳, 蔵本孝一

相談内容の概略「非臨床試験の充足性及び品質の妥 当性, 探索的治験プロトコールの各項目設定の妥当性」

\section{企業との連携}

2013年, (株林原（長瀬産業）と光電変換色素供給に ついて合意し, (株某社と医療用高純度ポリエチレン供 給について合意した。2013年10月 7 日, 経済産業省主 催「医工連携推進シンポジウム」(東京) で発表した。 2014年12月 26 日, 岡山県の三乗工業株式会社が人工網 膜の製造基礎技術に関して岡山大学と共同研究契約を 締結した。

2015年 1 月 31 日, 経済産業省の外郭団体である中小 企業基盤整備機構の岡山大インキュベータに入居し, 5 月にはクリーンルームの製造施設を構築した（図 6 ). この製造場所での企業による医療機器製造業登 録, 医療機器製造販売業許可申請について，2014年12 月に岡山県と相談を始めた。2015年中に先ず医療機器 製造業を岡山県に対して登録する予定である。製造は 当初は共同研究者の内田哲也が責任者となり, first-inhuman feasibility studyに治験機器を提供する. その 後, 時間をかけて企業に技術移転し, 続く pivotal study では企業が治験機器提供者となるようにする。

\section{POC（proof of concept）取得に向けた試験計画}

\section{1 . 非臨床 POC}

医療機器の生物学的安全性評価としての 6 力月埋植 試験を完了し，亜急性全身毒性試験を実施する。6力 月埋植による品質劣化の程度を判定する．品質の長期 安定性を予測する加速試験を確立し実施する. 加速酸 化試験は, 人工関節のポリエチレンの加速酸化試験に 準じて実施する. 光劣化試験では, 人工網膜に強度 (照 度）を変えた白色光を照射し, 光誘起表面電位を測定 する．可視吸光度計でも表面を測定する．有効性に関 する追加試験として細胞活動電位の反応を記録する.

\section{2 . 臨床 $\mathrm{POC}$}

1 ）試験の枠組み：医師主導治験 治験責任者（治験責任医師）：松尾俊彦
治験機器提供者：内田哲也

2 ) 試験の段階：First-in-human feasibility study

3 ）プロトコール骨子

(1)背景：網膜色素変性は遺伝性疾患で，次第に視野が 狭くなり，最終的には視力が下がって失明に至る疾 患である，現在，失明した患者に対する治療法はな い.

(2)原理 (Rationale)：光を電気信号（電位差）に変換 する人工物で視細胞の機能を代替する.

(3)試験デザイン：非盲検・単群・単施設臨床試験

(4)対象疾患：網膜色素変性

(5)適格基準：視力は「光覚なし」の眼

(6)主要 /副次評価項目 (エンドポイント) : 安全性/探 索的効果 (矯正視力・ゴールドマン視野), 判定時期 は術後 7 日目と 28 日目 $\rightarrow$ 長期安全性確認試験に移行 (7)測定する生物学的指標 (バイオマーカー) : 光干涉断 層計 (optical coherence tomography：OCT) によ る網膜層構造と網膜厚 ${ }^{18,19)}$

8)治療計画：局所麻酔下の硝子体手術（黄斑下手術）

による網膜下植込み

(9)観察期間： 2 年間

(10)目標症例数: 5 人

(11)質管理体制（生物統計家，Data Management，モ二 夕ー, 監査)：岡山大学病院・新医療研究開発センター

\section{おわりに}

治験開始の手前まで到達できたのは，患者の皆様か らの応援があるからこそと思う。医者は患者によって 活かされ，患者から学ぶと改めて実感する，他方，岡 山大学・研究推進産学官連携機構や岡山大学病院・新 医療研究開発センターによる支援と連携体制によって

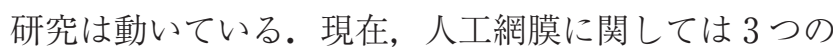
定例会議がある。1）人工網膜知財戦略委員会，2） PMDA 対応・研究進渉会合, 3) 共同研究・医療機器 等法対応会合である。

人工網膜の知的財産形成に関しては, 2014年度, 2015 年度と 2 年続けて特許庁の外郭団体である独立行政法 人・工業所有権情報・研修館の事業として, 岡山大学 には発明推進協会から知的財産プロデューサ（村井喜 博・岡山大学参与）が派遣されている. 知財戦略委員 会は知的財産本部で毎月開催されている.PMDA 対応 では，2015年 4 月，PMDA 審査専門員（臨床医学担 当）から新医療研究開発センターに移動された放射線 
科医の櫻井淳先生から助言を受けている．2014年度中 の PMDA 対応, 岡山県庁対応では, 石坂春彦・岡山 大学参与（帝人ナカシマメディカル(株取締役）から知 的支援を得ている。産学官連携本部の蔵本孝一・産学 官連携コーディネータは，人工網膜のプロジェクト・ マネジャーとして, PMDA 対応, 県庁対応, 研究全体 の調整を行っている.

2013～2014年度には, 臨床研究中核病院整備事業の 厚生労働科学研究費補助金（難病・がん等の疾患分野 の医療の実用化研究事業 (国際水準臨床研究分野)）を 受け，2015年 7 月からは, 日本医療研究開発機構の医 療研究開発推進事業費補助金「橋渡し研究加速ネット ワークプログラム・シーズ単年度 B」を受けて, 研究 を進めている。

2014年 9 月から全国 9 力所（旧 7 帝国大学十岡山大 学十慶應義塾大学）の革新的医療技術創出拠点となっ た岡山大学病院で, 世界初の医療機器である人工網膜 を患者さんに届けたいと思う。そして, 岡山の地から 世界に人工網膜を届けたいと思う。

\section{文献}

1) Ho AC, Humayun MS, Dorn JD, da Cruz L, Dagnelie G, Handa J, Barale PO, Sahel JA, Stanga PE, Hafezi F, Safran AB, Salzmann J, et al. ; Argus II Study Group : Long-Term Results from an Epiretinal Prosthesis to Restore Sight to the Blind. Ophthalmology (2015) 122,1547-1554.

2 ) 松尾俊彦: 光電変換色素を使った人工網膜試作品の開発. 岡山大学方式の人工網膜.「眼科に扔ける最新医工学. II. 視機能再生工学」. 臨床眼科 増刊号 (2005) 59, S118-122.

3 ) 松尾俊彦: 岡山大学方式の人工網膜の試作品. 光電変換色 素をポリエチレン・フィルムに固定した人工網膜の開発. 「特集：医療と画像処理」. 画像ラボ (2006) 17, 36-40.

4) 松尾俊彦: 視機能再生工学. 光電変換色素をポリエチレ ン・フィルムに固定した人工網膜 (岡山大学方式人工網膜) の開発.「特集：最近注目される脳神経疾患治療の研究」. Brain and Nerve (2007) 59, 331-338.

5 ) Matsuo T, Uchida T, Takarabe K : Safety, efficacy, and quality control of a photoelectric dye-based retinal prosthesis (Okayama University-type retinal prosthesis) as a medical device. J Artif Organs (2009) 12, 213-225.

6 ) 内田哲也, 松尾俊彦: 色素固定薄膜型人工網膜（岡山大学 方式人工網膜)の実用化に向けた医工連携の取り組み。「大 学発! 次世代を担う R\&D 特集」. 機能材料 (2014) 34, 4147.

7 ) 松尾俊彦, 内田哲也: 色素結合薄膜型の人工網膜 $\left(O U_{R e}{ }^{T M}\right)$ の医師主導治験を目指して.「特集：人工臟 器 一 最近の進歩」. 人工臟器 (2014) 43, 189-193.
8 ) Matsuo $\mathrm{T}$ : A simple method for screening photoelectric dyes towards their use for retinal prostheses. Acta Med Okayama (2003) 57, 257-260.

9) Matsuo T, Dan-oh Y, Suga S (Inventors), Okayama University (Assignee): Agent for inducing receptor potential. United States Patent. Patent No. US 7,101,533 B2. Date of Patent September 5, 2006.

10）松尾俊彦, 段王保文, 菅 貞治 (発明者), 岡山大学 (特許 権者）：受容器電位誘発剤のための有機色素化合物のスク リーニング方法. 特許第5090431号. 登録日2012年 9 月 21 日.

11) Uchida $T$, Ishimaru $S$, Shimamura $K$, Uji A, Matsuo $\mathrm{T}$, Ohtsuki H : Immobilization of photoelectric dye on the polyethylene film surface. Memoirs of the Faculty of Engineering Okayama University (2005) 39, 16-20.

12) Uji $A$, Matsuo $T$, Ishimaru $S$, Kajiura $A$, Shimamura $K$, Ohtsuki H, Dan-oh Y, Suga S : Photoelectric dye-coupled polyethylene film as a prototype of retinal prostheses. Aritif Organs (2005) 29, 53-57.

13) Uji A, Matsuo $T$, Uchida $T$, Shimamura $K$, Ohtsuki $H$ : Intracellular calcium response and adhesiveness of chick embryonic retinal neurons to photoelectric dye-coupled polyethylene films as prototypes of retinal prostheses. Artif Organs (2006) 30, 695-703.

14) Tamaki $T$, Matsuo $T$, Hosoya $O$, Tsutsui KM, Uchida $T$, Okamoto K, Uji A, Ohtsuki H : Glial reaction to photoelectric dye-based retinal prostheses implanted in the subretinal space of rats. J Artif Organs (2008) 11, 38-44.

15) Okamoto K, Matsuo $T$, Tamaki $T$, Uji A, Ohtsuki H : Short-term biological safety of a photoelectric dye used as a component of retinal prostheses. J Artif Organs (2008) $11,45-51$.

16) Alamusi, Matsuo $T$, Hosoya $O$, Tsutsui KM, Uchida $T$ : Behavior tests and immunohistochemical retinal response analyses in RCS rats with subretinal implantation of Okayama University-type retinal prosthesis. J Artif Organs (2013) 16, 343-351.

17) Alamusi, Matsuo $T$, Hosoya $O$, Tsutsui KM, Uchida $\mathrm{T}:$ Vision maintenance and retinal apoptosis reduction in RCS rats with Okayama University-type retinal prosthesis (OUReP ${ }^{\mathrm{TM}}$ ) implantation. J Artif Organs (2015) 17, [Epub ahead of print].

18) Matsuo $\mathrm{T}$, Morimoto $\mathrm{N}$ : Visual acuity and perimacular retinal layers detected by optical coherence tomography in patients with retinitis pigmentosa. Br J Ophthalmol (2007) 91, 888-890.

19) Tamaki M, Matsuo $T$ : Optical coherence tomographic parameters as objective signs for visual acuity in patients with retinitis pigmentosa, future candidates for retinal prostheses. J Artif Organs (2011) 14, 140-150. Erratum (2011) 14, 385. 